\title{
Helgefyll gir økt risiko for hjertesykdom
}

\author{
Mens et moderat alkoholforbruk er \\ forbundet med redusert risiko for \\ iskemisk hjertesykdom, kan det \\ å drikke seg beruset minst én gang \\ i uken øke risikoen.
}

Risikoen for kardiovaskulær sykdom synes å ha sammenheng med drikkemønsteret. Forskere har nå prospektivt sammenliknet insidens av iskemisk hjertesykdom hos 2405 menn fra Nord-Irland og 7373 menn fra Frankrike og knyttet denne til alkoholvanene (1).

Av dem som drakk alkohol, var det langt flere med et daglig inntak i Frankrike (75\%) enn i Nord-Irland (12\%). Det gjennomsnittlige forbruket var også større. Men nesten $10 \%$ av irene drakk seg beruset, definert som et alkoholinntak på $>50 \mathrm{~g}$ minst en dag i uken, mot bare $0,5 \%$ av franskmennene. Den årlige insidensen av hjerteinfarkt og koronar død var dobbelt så høy i Irland som i Frankrike. I hele kohorten og justert for kardiovaskulære risikofaktorer var risikoen for hjerteinfarkt og koronar død dobbelt så høy hos dem som drakk seg fulle som hos dem som drakk mindre om gangen.

- Studien støtter rapporter fra Finland og Russland om at det er sammenheng mellom et høyt alkoholinntak over kort tid og akutt hjerte- og karsykdom, sier professor Dag S. Thelle ved Institutt for medisinske basalfag, Universitetet i Oslo. - Typisk nok topper akutte kardiovaskulære hendelser seg på lørdag, søndag og mandag i disse landene, sier han.

- Også de som ikke drakk alkohol, hadde høyere risiko for iskemisk hjertesykdom enn de som hadde et moderat inntak. Et tilbakevendende spørsmål er hva annet som karakteriserer dem. I denne studien ble tidligere alkoholbrukere skilt ut som egen gruppe, men fortsatt hadde de avholdende høyere risiko enn de som drakk litt. Det viktigste budskapet er at helgefyll er langt farligere enn et jevnt kontrollert forbruk, sier Thelle.

\section{Trine B. Haugen}

trine.b.haugen@hf.hio.no

Tidsskriftet

\section{Litteratur}

1. Ruidavets J-B, Ducimetière $P$, Evans A et al. Patterns of alcohol consumption and ischaemic heart disease in culturally divergent countries: the Prospective Epidemiological Study of Myocardial Infarction (PRIME). BMJ 2010; 341: c6077.

\section{Behandling av bekkeninfeksjon}

Mange engelske kvinner som blir behandlet for akutt bekkeninfeksjon hos allmennlege blir ikke fulgt opp i henhold til retningslinjene (Br J Gen Pract 2010; 60: e395-406).

Kohortstudien omfattet 3800 kvinner i alderen 15-40 år som kom til lege med førstegangs akutt bekkeninfeksjon. Pasientene ble identifisert via diagnosekoder. Journalopplysninger 28 dager før og etter ble gjennomgått, og behandlingen ble sammenliknet med anbefalt terapi definert som enten erytromycin, ofloksacin, azitromycin eller doksysyklin med eller uten metronidazol.

I alt 2064 (56\%) ble utelukkende behandlet i allmennpraksis. Kun 15,5\% fikk det forfatterne anser for optimal behandling.

\section{Godt humør av blått lys?}

Lysbehandling kan være effektivt ved sesongbetonte depressive lidelser. Også lysets fargesammensetning kan påvirke hvordan hjernen bearbeider emosjonelle stimuli (Proc Natl Acad Sci 2010; 107: 19549-54).

Dette ble unders $ø$ kt ved hjelp av funksjonell MR. 17 unge, friske forsøkspersoner ble utsatt for alternerende blått og grønt lys i perioder på 40 sekunder, og det ble registrert hvordan de reagerte når de lyttet til hhv. sinte og nøytrale stemmer samtidig.

Det var høyere respons på emosjonelle stimuli i amygdala («stemmeområdet» i hjernen) og i hippocampus (viktig for hukommelsen) ved blått enn ved grønt lys. Blått lys førte også til tettere interaksjon mellom amygdala og hypothalamus, som er essensiell for å regulere biologiske rytmer ved hjelp av lyset.

\section{Gode erfaringer med å vente og se}

\section{Allmennleger mener at vent-og-se- resept er en god strategi ved hånd- tering av otitt og sinusitt i allmenn- praksis.}

Vent-og-se-resept innebærer at legen forskriver en vanlig resept på antibiotika og gir pasienten det råd å se an tilstanden en viss tid før man eventuelt starter med kuren. En slik avventende strategi kan redusere bruken av antibiotika ved luftveisinfeksjoner og er anbefalt i kliniske retningslinjer i flere land, inkludert Norge. Vi vet lite om hva allmennleger mener om vent-og-seresept og hvilke erfaringer de har med en slik strategi. I en studie fra norsk allmennpraksis er dette undersøkt nærmere (1).

Studien er basert på gruppeintervjuer med et utvalg på 33 allmennleger som deltok $i$ et kvalitetsforbedringsprosjekt hvor siktemålet var å forbedre forskrivningen av antibiotika ved luftveisinfeksjoner. De aller fleste deltakerne i studien var positive til vent-og-seresept og mente dette var et fornuftig alternativ, også i situasjoner hvor lege og pasient ikke nødvendigvis hadde ulik oppfatning om behovet for antibiotika. Legene mente at strategien var spesielt egnet ved tilstander hvor symptomvarigheten ville være avgjørende for om antibiotika var indisert eller ikke, som akutt otitt og sinusitt. De understreket at bruk av vent-og-se-resept

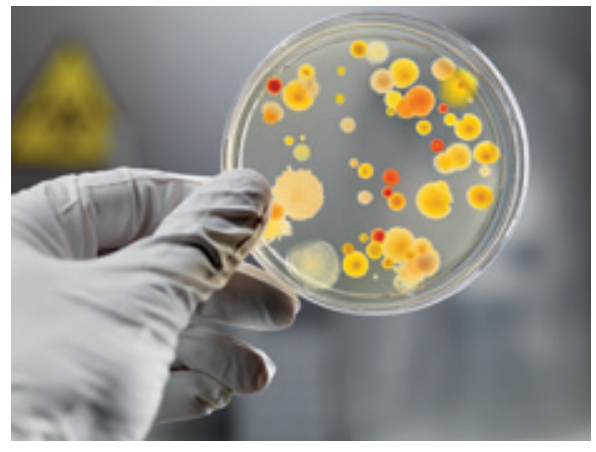

Illustrasjonsfoto Istockphoto

forutsatte at man tok seg tid til å gi grundig informasjon til pasienten om når det ville være riktig å starte en eventuell kur og at den aktuelle pasienten eller de pårørende var i stand til å ta løpende stilling til dette.

Resultatene fra studien vil kunne få betydning for utforming og implementering av retningslinjer for antibiotikabruk i allmennpraksis.

\section{Sigurd Høye}

sigurd.hoye@medisin.uio.no

Avdeling for allmennmedisin

Universitetet i Oslo

Litteratur

1. Høye S, Frich J, Lindbæk M. Delayed prescribing for upper respiratory tract infections: a qualitative study of GPs' views and experiences. Br J Gen Pract 2010; 60: 907-12. 